\title{
クリーン・ヘルス・ビューティー事業活動を支える先端ライフテクノロジー ーライオン株式会社一
}

奥 村 統

当社における技術革新の原点は健康生活業を根幹と しつつライフテクノロジー企業へ脱皮するための研究開 発戦略にある。オーラルケア，ホームケアメディアケ ア，スキン・ヘアケア，フード，メディカル，サ二タリ 一、ケミカルなど生活に密着した製品を生み出す技術は 以下の7つの科学技術分野の革新技術がインテグレート された結果である。

\section{1. 界面科学}

物質と物質が触九合う場には必ず界面があり，そこに 起きる様々な現象を解明するのが界面科学であり，その 界面の性質を積極的に变える物翼が界面活性剂である。 洗剂の主成分である界面活性剤は污れと基質の界面に吸 着してその付着エネルギーを低下させ污れを取れ易くす る。古くは石铪から一世を風びした「トッフ」のAOS ( $a$ ーオレフィンスルホホート)に至るまで洗用の歴史は 最初は洗えばきれいになる触生分野から泡公害、富栄㻎 化防止のエコロジー対策となり，今や肌や䣼に秲して マイルドな界面活性剤の選択とライフサイエンスの領城 に入ってきている。ライオンが世界に先駆けて開発した AOS は数々の技術賞に輠き，当初は生分解の早い界面 活性剂を租ったものが生体上の植容性が優れていること が判り，最近ではEOR 薬郕として脚光を浴びている。 界面活性戍は近末来のエネルギーと言われているCOM やCWMをつくるキー・マテリアルで当社と電源開発公
団で共同開発したPSSは発電所での塞証運転を始め次 の商用運転に備えている。

\section{2. 口監科学}

蒾を磨く習慣が衛生思想の普及と共に口腔科学と言わ れるまで発展してきた。当社はムシ娄や整槽膙漏の成因 の解明により口腔内の清净; 美白から予防・治璄に至る までトータルシステムを提供する研究を行っている。齿 垢を分解してムシ菌を予防するデキストラナーセ喽菜を 配合した「クリニカ」、歯ぐきのハレや出血を防せくた め抗プラスミン剂配合の「デンターT」は何れも醅, 医薬成分を初めて荬磨に応用した画期的な商品である。 またTDKと共同で開発した顆粒状多孔性水酸化了バ夕

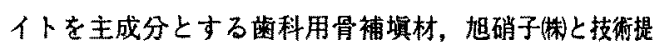
携しリン酸カルシウム系ガラスを素材にした人工紫な ど生体適合性材料の開発も進んでいる。

\section{3. 油脂科学}

天然油脂を分解して脂肪酸，梍級アルコール，ダリセ

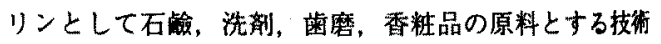
は古くから当社の得意とする分野であったが，石油化学 全盛㭙代安価な合珹原料に压され油脂事業は採算が职れ す撤退していた。しかしこの間研究は中断することなく 継続し，このほど革新的な技術の確立により香川県圾出 市に油脂事業を展開するたか工事に着工した。用地8万

油脂事業フローチャート

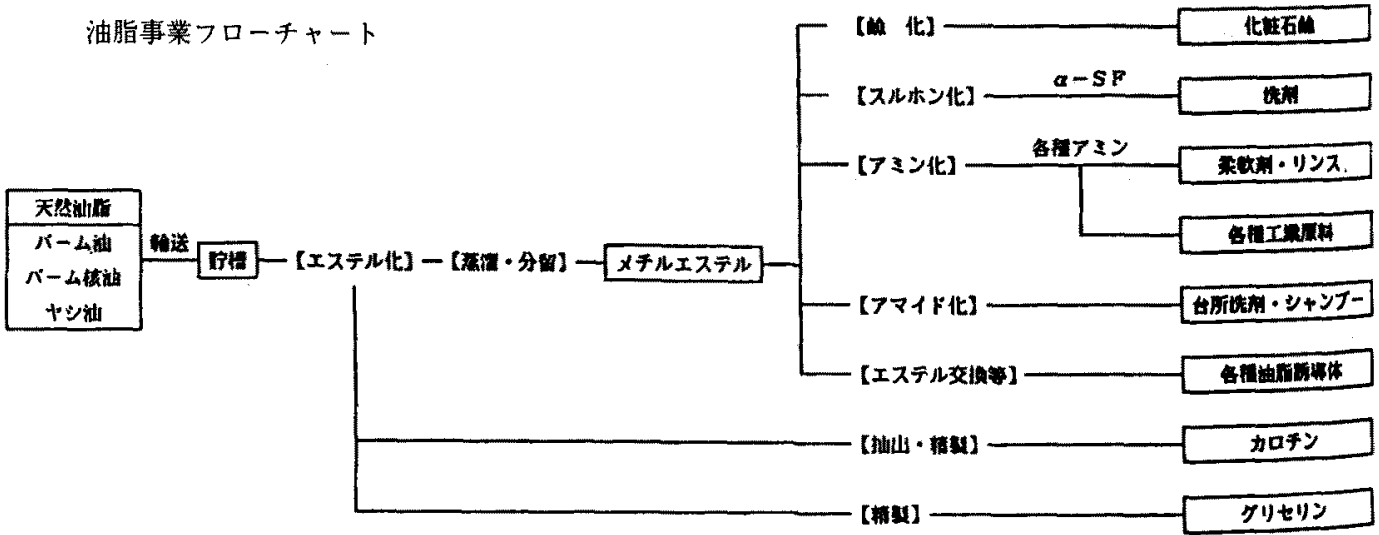


坪年産能力 7 万トン規模のプロジェクトの概要はフロー チャートに示すが，革新技術の特徴は以下の通りであ る。原料油脂を取り扱い容易なメチルエステルとし，衣 料用・台所用洗剂, シャンプー・リンス, 柔軟剂, 各種 工業製品とする。他方パーム油のエステル化工程でカロ チンを奻率的に抽出・精製する技術を世界で初めて確立 した。油脂からのカロチン抽出は油脂企業にとっては重 要なテーマでこれまで吸着法, 溶鼡分別法, 蒸溜法など の研究が進められてきたが実用化されるに至っていな い。僅かにスイスのロッシュ社が合成法でßーカロチン を企業化しているに過ぎない。ガンンカボチャや人 参など緑黄色野菜に含まれる色素で体内でビタミン A に変ることから栄美色素として注目されてきた。特に米 国ではカロチンあるいはビタミン A の発癌抑制効果に 関心か強く，その作用についての研究が盛んである。パ 一ム为ロチンは $\alpha$ 体を約 $35 \% ， \beta$ 体を約 $65 \%$ 含むが, 当 社上京都府立医大の共同研究の結果マウスに対する $\alpha$ カロチンの抗ガン効果は $\beta$ ーカロチンの10倍も優れてい ることが判かり，その上ガン細胞を正常細胞に戻寸分化 誘導作用のあることをつきとめ，昨秋の日本癌学会で発 表された。世界でも類を見ないこの天然カロチンはカプ セル慗绪，顆粒品，油性分散物として米国などに輸出さ れるほか，機能性食品用にも用途開拓していく予定で, カロチンを柱とした油脂事業も食品, 医薬品事業への展 開と大きな期待がかけられる。天然物中の有用成分の抽 出技術の水平展開として，血液循環との関連で注目され ている $\gamma$-リノレン酸の他, 子宮筋収縮, 血管拡張, 血 压降下など多彩な生理活性を持つプロスタグランジンの 前駆物質として注目されているアラキドン酸を 3 倍以上 奻率的に生産する禾状菌を発見し，これを脂質加抽出 する技術へ発展している。

\section{4. 毛管・皮科学}

琹と肌の健康とその老化防止技術の多角的な展開を進 めているが、ここでも自然の生態系は崩さない, ホルモ ンそのものには触らないことを研究の原点としている。 毛琵へのエネルギー供給による新育毛理論の展開, 角質 の代湖を調整してフケの発生を㧕制する成分の開発，シ ミ・ソバカス・白譆の原因となるメラニン色素の代謝メ カニスム解明による予防物質の発見, 肌荒れや堭の損傷 と界面活性剂の相互作用をつきとめ，その低隇方法の提 案, 二キヒ, 水虫に対する表皮角質, 抗真菌骩の研究な と, その先端技術はユニークな商品作りに活用されてい 万。

\section{5. 高分子科学}

新しい機能性高分子の開発と応用の例として高吸水性 樹脂による高性能生理用品がある。またサブミクロン単 位の反応性ミクロゲルは耐水性・耐薬品性に優れ叙料, 接着郕, コンクリート混和郕, エレクトロニクス用素材 へと応用範囲は広い。樹脂マトリックスにケッチェンブ ラックや金属粉末を分散させた導電性コンバウンドは電 磁波シールド材に，真空蒸着法で作った高飽和磁化をも つ磁性流体は真空シールやダンパー用に，ポリアクリル 酸部分中和物水溶液の散布による不透水層の形成技術は 塩害防止と節水効果により砂漠の緑地化に多大の期待が かけられ，東大農学部と共同開発中である。

高分子環状化合物によるリチウムなどのレアメタルの 捕集片, 真空ポンプ油として開発したアルキルナフタレ ンベースの合成油は従来の石油系に比べ 5 -20倍の寿命 と高い粘度指数をも古半尊体製造装置用高真空化技術に 最適である。

\section{6. カプセル科学}

直径 $100 \mu$ のカプセルに揮発性香料を封じ込め, 使う 度に何時も新鮮な香りが漂う「エメロンフレグランス石 睑」は石眮一個に20万粒のマイクロカプセルが配合さ れ、この技術は室内芳香郕「ピコレットカプセル」、 、 ッコーミック「粉わさび」にも応用され，最先端技術が 僅か数百円で買える商品に詰まっていると好評である。

\section{7. 生命科学}

洗郕の生態系への安全性確認から始まったのが当社の バイオ研究で, そこから微生物や䤃素, 生薬, 植物・動 物バイオへと領域を広げた。醇素洗剂で先鞭をつけたの は当社であるが，その後極北地から耐アルカリ性，耐界 面活性剂性に優れたY 酔素を発見する技術に繁がっ た。薬効生薬や天然植物の研究からアロエ ECW 配合の 基整化粧品『アプティ』を生み, 東北大との共同研究で 海草アラメにフラボンの 3 倍, クロロフィルの6 倍のロ 奥抑制効果を発見し、香辛料メースに強い抗ガン作用を もつフェノール系物質を見つけ，毛状根から天然の1000 倍の収率でシコニンを得る技術が展開された。また鋼管 清水サービス俶と共同でオニテナガエビの養殖，キチ ン,キトサン誘導体の開発などにも意欲を燃やしてい る。自然な眠りを誘う医家向け催眠郕「リストミン S」 は15年の藏月を掛けた研究成果であり、これを生み出し た生物科学研究所はGLP 対応の実験棟の新設も完了 し, 当社の誇るバイオテクノロジーのメッカとして今後 の進展が期待される。 